\title{
Antibacterial Property and Molecular Docking Studies of Leaf Calli Phytochemicals of Bridelia scandens Wild.
}

\author{
Ravikumar Shivakumar, Krishna Venkatarangaiah, Sudhesh Shastri, Ravishankara Burladinni Nagaraja, Ajith \\ Sheshagiri
}

\section{Ravikumar Shivakumar, Krishna Venkatarangaiah, Sudhesh Shastri, Ravis- hankara Burladinni Naga- raja, Ajith Sheshagiri}

Department of PG Studies and Research in Biotechnology, Kuvempu University, Shankaraghatta, Shivamogga,

Karnataka, INDIA.

Correspondence

Krishna Venkatarangaiah

Professor, Department of PG Studies and Research in Biotechnology, Kuvempu University, Shankaraghatta, 577 451, Shivamogga District, Karnataka INDIA.

Phone no : +91 9448681856/ 08282-256301 (O)

E-mail: krishnabiotech2003@gmail.com History

- Submission Date: 10-05-2018:

- Review completed: 05-07-2018;

- Accepted Date: 10-08-2018

DOI : 10.5530/pj.2018.6.209

Article Available online

http://www.phcogj.com/v10/i6

\section{Copyright}

(C) 2018 Phcog.Net. This is an openaccess article distributed under the terms of the Creative Commons Attribution 4.0 International license.

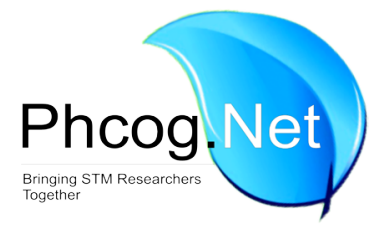

\begin{abstract}
Background: Bridelia scandens Wild. (Euphorbiaceae) leaves are widely used to cure asthma, bronchitis pleurisy, exudation, sores in mouth and genital cancers. Objective: To evaluate antibacterial activity of the leaf calli methanol extract (LCME). Materials and Methods: Mass production of leaf calli was established on MS medium supplemented with $0.5 \mathrm{mg} / \mathrm{L} \mathrm{BAP}$ and $0.5 \mathrm{mg} / \mathrm{L} 2$, 4-D. Methanol extract of the dried calli was subjected to HR-LCMS analysis, antibacterial screening of the extract was carried out against human pathogenic clinical isolates. Molecular docking study of HR-LCMS identified compounds was performed by docking with bacterial enzyme DNA gyrase. Results: HR-LCMS analysis of LCME shows that the compounds azaperone bifonazole, fusidic acid, lasalocid and quinine as the major constituents. The antibacterial screening of LCME against clinical pathogens showed significant bactericidal activity against the strains Staphylococcus aureus (17.67 $\pm 0.88 \mathrm{~mm}$. d.), Streptococcus pneumonia (13.67 \pm 0.33$)$, Pseudomonas aeruginosa (16.33 \pm 0.67$)$, Salmonella typhi $(17.67 \pm 0.33)$, and Vibrio cholera (15.33 \pm 0.33 ) as compared to the standard drug ciprofloxacin. The molecular docking of lasalocid against the bacterial enzyme DNA gyrase exhibited good binding affinity of $-4.9 \mathrm{kcal} / \mathrm{mol}$, good drug likeness (2.5589), 2 hydrogen bonds and hydrophobic interaction with 7 amino acid residues, so that lasalocid processes good inhibitor as compared to other 4 compounds. Conclusion: LCME of Bridelia scandens showed significant antibacterial activity against Staphylococcus aureus and Salmonella typhi. Lasalocid is the major phytocomponent of LCME which exhibited good inhibitory activity against bacterial enzyme DNA gyrase. This investigation supported traditional claim of LCME as potential antibacterial drug.
\end{abstract}

Key words: Bridelia scandens, Antibacterial, ADMET, DNA Gyrase, Molecular docking.

\section{INTRODUCTION}

Since earliest times, medicinal plants have been known to exert healing properties against human infections as antimicrobial agents due to the presence of rich secondary metabolites. Unscientific collection and over exploitation of medicinal plants resulted in the dwindling of natural population and many of them are at the verge of threatening status. Induction of callus from the medicinal plant parts and in vitro production of secondary metabolites from the calli is a novel technique for sustainable conservation of medicinal plants. So that callus culture is the process that can reduce the time and season as it does not need to have the whole plant cultivation and sacrificing it for extraction. ${ }^{1}$

Bridelia scandens is a straggling climber belongs to the family Euphorbiaceae. It is distributed in the warm regions of Southeast Asia ${ }^{2}$ and also in Western peninsular India especially in deciduous to semi-evergreen forests of Maharashtra, Kerala, Karnataka states (http:// www.indiabiodiversity.org). In traditional medicine, decoction of the leaves has been used in the treatment of asthma, cough, fever, pleurisy, exudation and sores in mouth. The phytochemical examination of the B. scandens leaves showed the presence of flavonoids, carbohydrates, glycosides, phenolic compounds and tannins. ${ }^{3}$ In the previous study an anticancerous compound anthrisine-deoxypodophyllotoxin was isolated from the leaves of $B$. scandens. ${ }^{4}$

Over the past decade, much attention has been placed on the study of phytochemicals for their antibacterial activity, especially against multidrug-resistant Gramnegative and Gram-positive bacteria. ${ }^{5}$ The emergence of multidrug-resistance among bacteria has challenged the effectiveness of antibiotics in the advent of modern medicine and as such, antibiotic resistance has become one of the most serious health care problems in the world. ${ }^{6}$ Considering the above, there is a need to develop new effective antibacterial agents that circumvent the emergence of resistance. Nevertheless, the discovery of new antibiotics is very expensive and time consuming, requiring about ten

Cite this article: Shivakumar R, Venkatarangaiah K, Shastri S, Nagaraja RB, Sheshagiri A. Antibacterial Property and Molecular Docking Studies of Leaf Calli Phytochemicals of Bridelia scandens Wild. Pharmacog J. 2018;10(6):1221-9. 
years to bring a new antibiotic to market. Therefore, the search for antibacterial substances derived from natural products, such as phytochemicals, has gained cumulative importance. ${ }^{7}$

In addition, in silico prediction of the ADMET properties plays an important role in antibiotic drug discovery process. Nowadays ADME (absorption, distribution, metabolism and elimination) is applied at an early phase of the drug development process, in order to remove molecules with poor ADME properties from the drug development pipeline and leads to significant savings in research and development costs. Lipinski "Rule of five" is widely used as a filter for drug-like properties. ${ }^{8}$ Molecular docking is a frequently used method for evaluating the complex formation of small ligands with large biomolecules. ${ }^{9}$ In view of the above, the present investigation was undertaken to isolate and characterize antibacterial compounds from the in vitro derived leaf calli and to authenticate the antibacterial property against human pathogenic clinical isolates.

\section{MATERIALS AND METHODS}

\section{Plant material and callus culture}

Mesristematic leaf explants of B. scandens was collected from Bhadra Wild Life Sanctuary of the Western Ghats ( $1 \mathrm{~km}$ from Kuvempu University) and was identified by Prof. V Krishna, professor and taxonomist, Dept. of Biotechnology, Kuvempu University.

The leaves were cleaned with deionized water, sterilized with $5 \%$ tween-20, $0.2 \%$ mercuric chloride, followed by distilled water wash and then $1 \mathrm{~cm}$ aseptically inoculated on to MS semi solid media supplemented with hormonal concentration of $0.5 \mathrm{mg} / \mathrm{L} \mathrm{BAP}$ and $0.5 \mathrm{mg} / \mathrm{L} 2,4-\mathrm{D}$ for callus initiation. The calli was subcultured on the same media and mass propagated for 4-6weeks. The calli was harvested, dried in hot air oven at $40^{\circ} \mathrm{C}$ for 4 to 5 days.

\section{Preparation of Extract}

About $186 \mathrm{~g}$ of dried callus was subjected for cold extraction with methanol for about $48 \mathrm{~h}$. The extract was sieved (Whatman No.1 filter paper) and concentrated in vacuum under reduced pressure using rotary flash evaporator (Buchi, Flawil, Switzerland) and dried at desiccator.

\section{Phytochemical screening Determination of total phenol}

Total phenol content in leaf callus methanol extract LCME was estimated by the Folin-Ciocalteu method. ${ }^{10} 1 \mathrm{ml}$ of LCME $(50 \mu \mathrm{g})$ was mixed with Folin-Ciocalteu reagent $(2 \mathrm{ml}$ ) (diluted $1: 10, \mathrm{v} / \mathrm{v}$ ) followed by the addition of $2 \mathrm{ml}$ of sodium carbonate $(7.5 \%, \mathrm{w} / \mathrm{v})$ and mixed, allowed to reaction for $90 \mathrm{~min}$ at room temperature and absorbance was measured against the blank at $750 \mathrm{~nm}$ using spectrophotometer (Systronics, PC based double beam spectrophotometer 2202). Total phenol content of the extract was expressed in terms of equivalent to gallic acid (GAE, $\mathrm{mg}^{-1}$ of dry mass).

\section{Determination of total flavonoid}

Total flavonoid content of LCME was measured according to the modified method of Zhishen. ${ }^{11} 5 \mathrm{ml}$ of extract $(200 \mu \mathrm{g})$ was mixed with $300 \mu \mathrm{l}$ of $5 \%$ sodium nitrite and $300 \mu \mathrm{l}$ of $10 \%$ aluminum chloride followed by the addition of $2 \mathrm{ml}$ of $1 \mathrm{M}$ sodium hydroxide after the incubation of reaction mixture at room temperature for $6 \mathrm{~min}$. The volume in each test tube was made up to $10 \mathrm{ml}$ by adding $2.4 \mathrm{ml}$ of millipore water. Absorbance was measured at $510 \mathrm{~nm}$ against the blank. Total flavonoid content of the extract was expressed in terms of equivalent to catechin $\left(\mathrm{mg}^{-1}\right.$ of dry mass).

\section{Determination of alkaloid}

Alkaloid determination using Harborne method:12 $5 \mathrm{~g}$ of the sample was weighed into a $250 \mathrm{ml}$ beaker and $200 \mathrm{ml}$ of $10 \%$ acetic acid in ethanol was added and covered and allowed to stand for $4 \mathrm{~h}$. This was filtered, and the extract was concentrated on a water bath to one-quarter of the original volume. Concentrated ammonium hydroxide was added drop wise to the extract until the precipitation was complete. The whole solution was allowed to settle and the precipitated was collected and washed with dilute ammonium hydroxide and then filtered. The residue is the alkaloid, which was dried and weighed.

\section{HR-LCMS analysis of LCME}

The bioactive components of $B$. scandens leaf callus extract was analyzed by High Resolution Liquid Chromatograph Mass Spectrometer (HR-LCMS) G6550A system (Agilent technologies). The method used for Chromatography was 30 mins \pm ESI 10032014_MSMS.m. The Gas temperature used for analysis was $250^{\circ} \mathrm{C}$. The theoretical mass of protonated compound was used for identification. HR-LC-MS analysis of $B$ scandens bark extracts was performed at Sophisticated Analytical Instrument Facility (SAIF), Indian Institute of Technology, Mumbai, India. The compounds were identified by comparison with their retention time (RT) and mass with stored metlin library available with IIT, Bombay.

\section{Antibacterial activity Microbial strains}

The antibacterial activity of the LCME was individually tested against a set of five bacterial human pathogenic clinical isolates obtained from Shivamogga Institute of Medical Sciences, Shivamogga, Karnataka, namely: Staphylococcus aureus, Streptococcus pneumoniae. Pseudomonas aeruginosa, Salmonella typhi, and Vibrio cholera, Bacterial isolates were cultured overnight at $37^{\circ} \mathrm{C}$ in nutrient agar (NA) media.

\section{Disk diffusion assay}

Determination of antibacterial activity of LCME was evaluated by agar well diffusion method. The extract was dissolved in DMSO at different concentrations $(500,1000$ and $1500 \mu \mathrm{g} / \mathrm{ml}$ of DMSO $\mu \mathrm{g}) .100 \mu \mathrm{l}$ of the suspension containing $10^{8}$ colony forming units $\mathrm{CFU} / \mathrm{ml}$ of bacteria were spread on NA media, respectively. Wells were made on agar plates using sterile cork borer, and $20 \mu \mathrm{l}$ of LCME of each concentration were introduced into appropriately marked wells, ciprofloxacin $(20 \mu \mathrm{g} / \mathrm{ml})$ was taken as a positive control. Then culture plates incubated for $24 \mathrm{~h}$ at $37^{\circ} \mathrm{C}$. Antibacterial activity was assessed by measuring the diameter of the growth inhibition zone in millimeters for the test organisms compared to the control. Activity index was calculated for comparison of the zone of inhibition of test material with standard antibiotic using the formula AI (Activity Index) = ZI of Test/ZI of Standard. ${ }^{13}$

\section{Minimum Inhibitory Concentration (MIC)}

The MIC of the LCME was evaluated by modified resazurin (7-Hydroxy$3 \mathrm{H}$-phenoxazin-3-one 10 -oxide) microtitre plate assay. ${ }^{14} 50 \mu \mathrm{l}$ of test sample containing $250 \mu \mathrm{g}$ of extract $[5 \mathrm{mg} / \mathrm{ml}(\mathrm{w} / \mathrm{v})]$ solutions in $10 \%$ dimethyl sulfoxide (DMSO, v/v) and $50 \mu \mathrm{g}$ of standard antibiotic $[1 \mathrm{mg} / \mathrm{ml}$ $(\mathrm{w} / \mathrm{v})$ ] solutions in $10 \%$ DMSO. $50 \mu \mathrm{l}$ of nutrient broth was added to all wells (microtitre plate). Two-fold serial dilutions were performed using a pipette such that each well had $50 \mu \mathrm{l}$ of the test material in serially descending concentrations. $30 \mu \mathrm{l}$ of 3.3 times stronger hi sensitivity broth and $10 \mu \mathrm{l}$ of resazurin indicator solution (prepared by dissolving $27 \mathrm{mg}$ resazurin in $4 \mathrm{ml}$ of sterile distilled water) were added to each well. Finally, $10 \mu \mathrm{l}$ of bacterial suspension was added to the appropriate wells to achieve a concentration of approx $5 \times 10^{6} \mathrm{CFU} / \mathrm{ml}$. The analysis of variance (ANOVA) was performed using ezANOVA (version 0.98) software and Microsoft excel to determine the mean and standard error. 


\section{Molecular docking studies}

Lipinski "Rule of five" is commonly used as a filter for drug-like properties. ${ }^{8}$ The in silico pharmacokinetic properties and ADME (absorption, distribution, metabolism and elimination) and toxicity analysis were predicted using Data Warrior (http://www.openmolecules.org/datawarrior.html). Data Warrior tries to assess the toxicity risk by finding substructures within the chemical structure being indicative of a toxicity risk within one of said four major toxicity classes.

The chemical structure of HR-LCMS identified compounds namely, azaperone, bifonazole, fusidic acid, lasalocid and quinine and the standard drug ciprofloxcin were drawn using Chem Bio Draw tool (Chem Bio Office Ultra 14.0 suite) assigned with proper 2D orientation, and structure of each was checked for structural drawing error. Energy of each molecule was minimized using ChemBio3D. The energy minimized ligand molecules were then used as input for AutoDock Vina, in order to carry out the docking simulation. The protein data bank (PDB) coordinate file with the name '2XCT.pdb' was used as receptor molecule. ${ }^{15}$ All the water molecules were removed from the receptor. The graphical user interface program MGL tool was used to set the grid box for docking simulations. The grid was set so that it surrounds the region of interest in the macromolecule. The grid box volume was set to 8, 14, and $14 \AA$ for $\mathrm{x}, \mathrm{y}$, and $\mathrm{z}$ dimensions, respectively, and the grid center was set to 3.194, 43.143, and 69.977 for $\mathrm{x}, \mathrm{y}$, and $\mathrm{z}$ center, respectively, which covered all the ten amino acid residues in the considered active pocket. The docking algorithm provided with AutoDock Vina was used to search for the best docked conformation between ligand and protein. During the docking process, a maximum of ten conformers were considered for each ligand. Molecular docking was performed in Corei5 Intel processor CPU with 6 GB DDR3 RAM. AutoDock Vina ${ }^{16}$ was compiled and run in a Windows 8.0 professional operating system. LigPlot $+{ }^{17}$ and PyMol educational version were used to deduce the $2 \mathrm{D}$ and $3 \mathrm{D}$ pictorial representation of the interaction between the ligands and the receptor. The ligands are represented in green colour, $\mathrm{H}$-bonds with their respective distances are represented with cyan colour, and the interacting residues are represented in ball and stick model representation.

\section{RESULTS}

\section{Callus culture}

Leaf explants of $B$ scandens proliferated into callus mass on MS media fortified with $0.5 \mathrm{mg} / \mathrm{l} \mathrm{BAP}$ and $0.5 \mathrm{mg} / \mathrm{l} 2$, 4-D. Callus induction was noticed from the cut end of the lamina and dorsal vein of the explants (Figure 1). Subculturing of the calli on to the same media induced luxuriant proliferation of the fleshy callus mass. After 6 weeks, the callus mass was harvested and fresh weight was found to be $3000 \mathrm{~g}$ the calli mass was dried in oven at $40^{\circ} \mathrm{C}$ for 4 days and dry weight was found to be $200 \mathrm{~g}$ of the dried calli mass was extracted with methanol used for phytochemical and antibacterial screening.

\section{Phytochemical analysis}

The preliminary phytochemical analysis of LCME showed positive result for qualitative tests for the phytochemicals alkaloids, flavonoids, and phenolics (Table 1). In quantitative analysis total polyphenolic content in LCME was expressed as equivalent to gallic acid (GAE) and is found to be $37.2 \mu \mathrm{g} / \mathrm{mg}$ of dry extract. The flavonoid concentration of LCME was expressed as equivalent to catechin and is found to be $56.9 \mu \mathrm{g} / \mathrm{mg}$ of dry extract. The alkaloid concentration of LCME was found to be $63.4 \mu \mathrm{g} / \mathrm{mg}$ of dry extract as depicted in the Table 1.
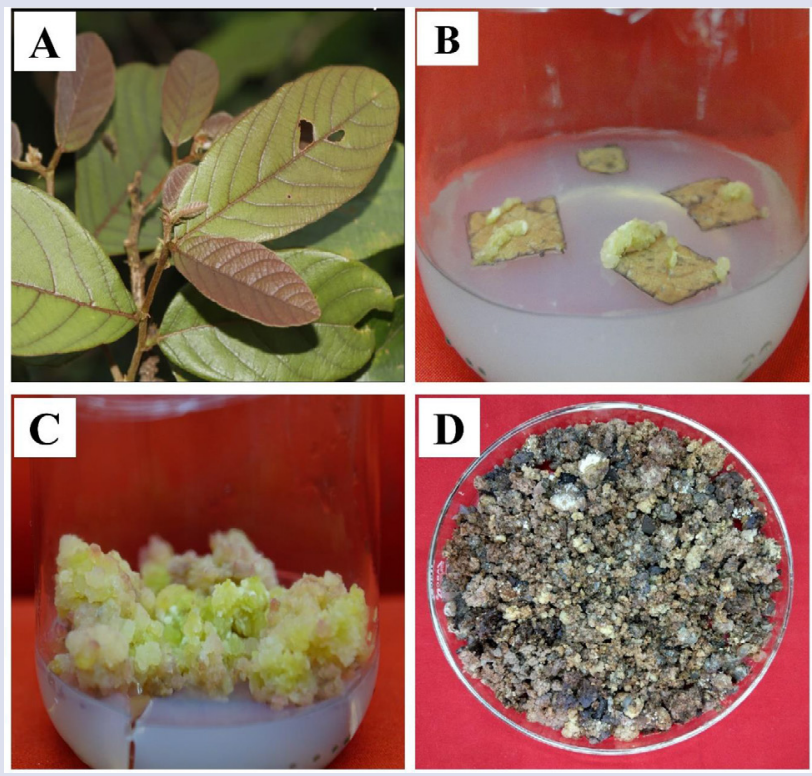

Figure 1: Callus induction from the leaf segments of Bridelia scandens A-Bridelia scandens collected from Bhadra Wild Life Sanctuary of Western Ghats, India. B-Callus induction from the excised lamina of B. scandens on MS media with $0.5 \mathrm{mg} / \mathrm{L} \mathrm{BAP}$ and $0.5 \mathrm{mg} / \mathrm{L}$ 2, 4-D.

C-Mass production of callus. D-Dried leaf calli mass of $B$. scandens.

Table 1: Qualitative and Quantitative analysis of B. scandens LCME.

\begin{tabular}{ccc} 
& Qualitative test & Concentration $\mu \mathrm{g} / \mathrm{gm}$ \\
\hline Alkaloids & + & $63.4 \mu \mathrm{g} / \mathrm{gm}$ \\
Flavonoids & + & $56.9 \mu \mathrm{g} / \mathrm{gm}$ \\
Steroids & - & - \\
Terpenoids & - & - \\
Cardiac glycosides & - & - \\
Saponins & - & - \\
Tannins & - & - \\
Phenols & + & $37.2 \mu \mathrm{g} / \mathrm{gm}$ \\
\hline
\end{tabular}

MCE - Methanol Callus extract, +: Present and -: Absent.

\section{HR-LCMS analysis}

HR-LCMS analysis of LCME resulted the presence of 100 phytoconstituents (Table 2) and the chromatogram of the phytoconstituents is shown in Figure 2. Among them the compounds azaperone, bifonazole, fusidic acid, lasalocid and quinine were known for antibacterial properties.

\section{Antibacterial activity}

The antibacterial activity of LCME was evaluated at the concentrations of 500, 1000 and $1500 \mu \mathrm{g} / \mathrm{ml}$ of DMSO. $1500 \mu \mathrm{g} / \mathrm{m} 1$ concentration shows significant antibacterial property noticed against clinical pathogen strains Staphylococcus aureus (17.67 \pm 0.88 mm.d.), Streptococcus pneumonia (13.67 \pm 0.33$)$, Pseudomonas aeruginosa (16.33 \pm 0.67$)$, Salmonella typhi (17.67 \pm 0.33$)$, and Vibrio cholera $(15.33 \pm 0.33)$, as compared to the standard drug ciprofloxacin. The MIC assay was performed by modified resazurin assay the extract shows highest inhibitory activity against 
Table 2: Phytoconstituents of leaf calli Methanol extract obtained from HR-LCMS.

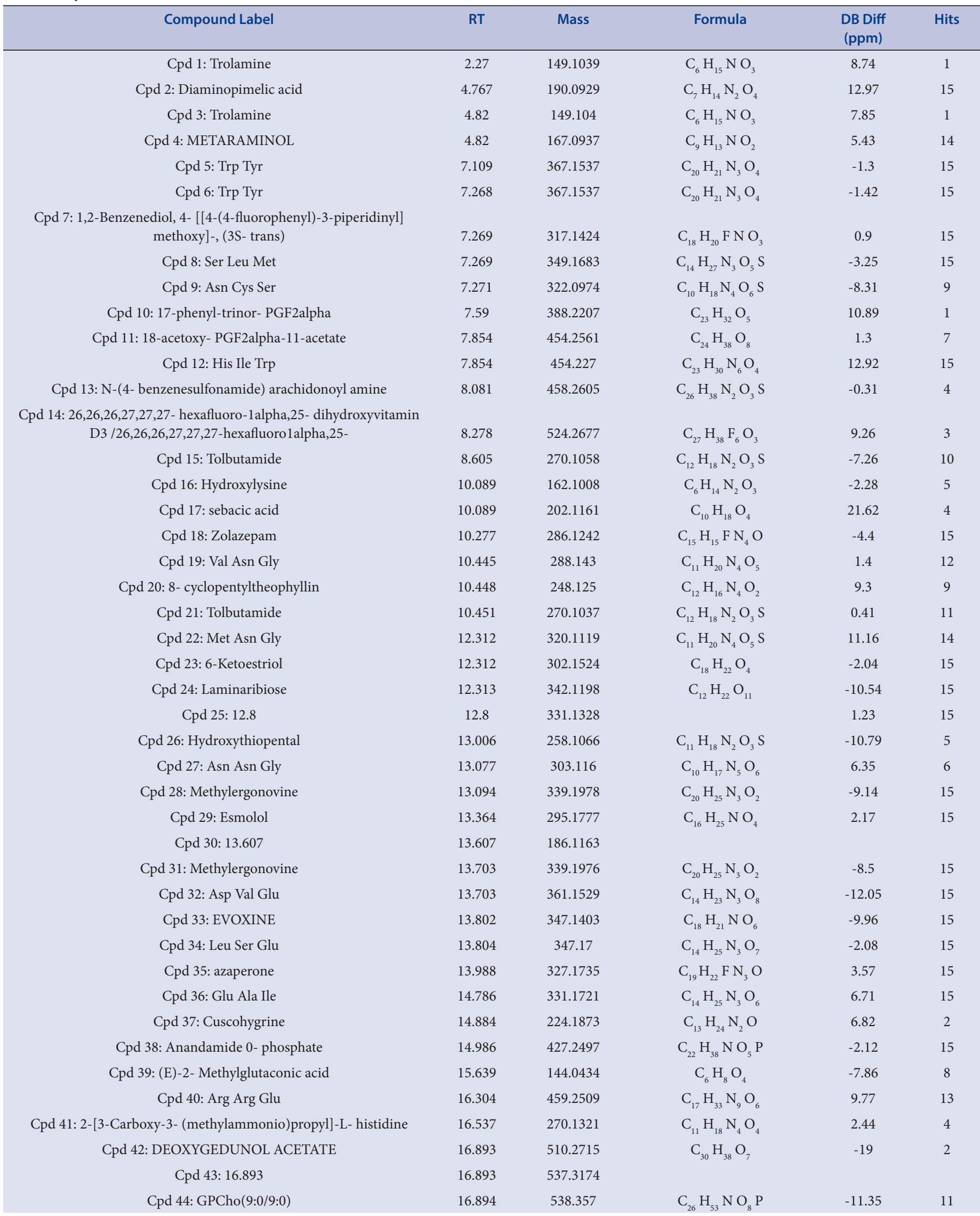


Table 2: Cont'd.

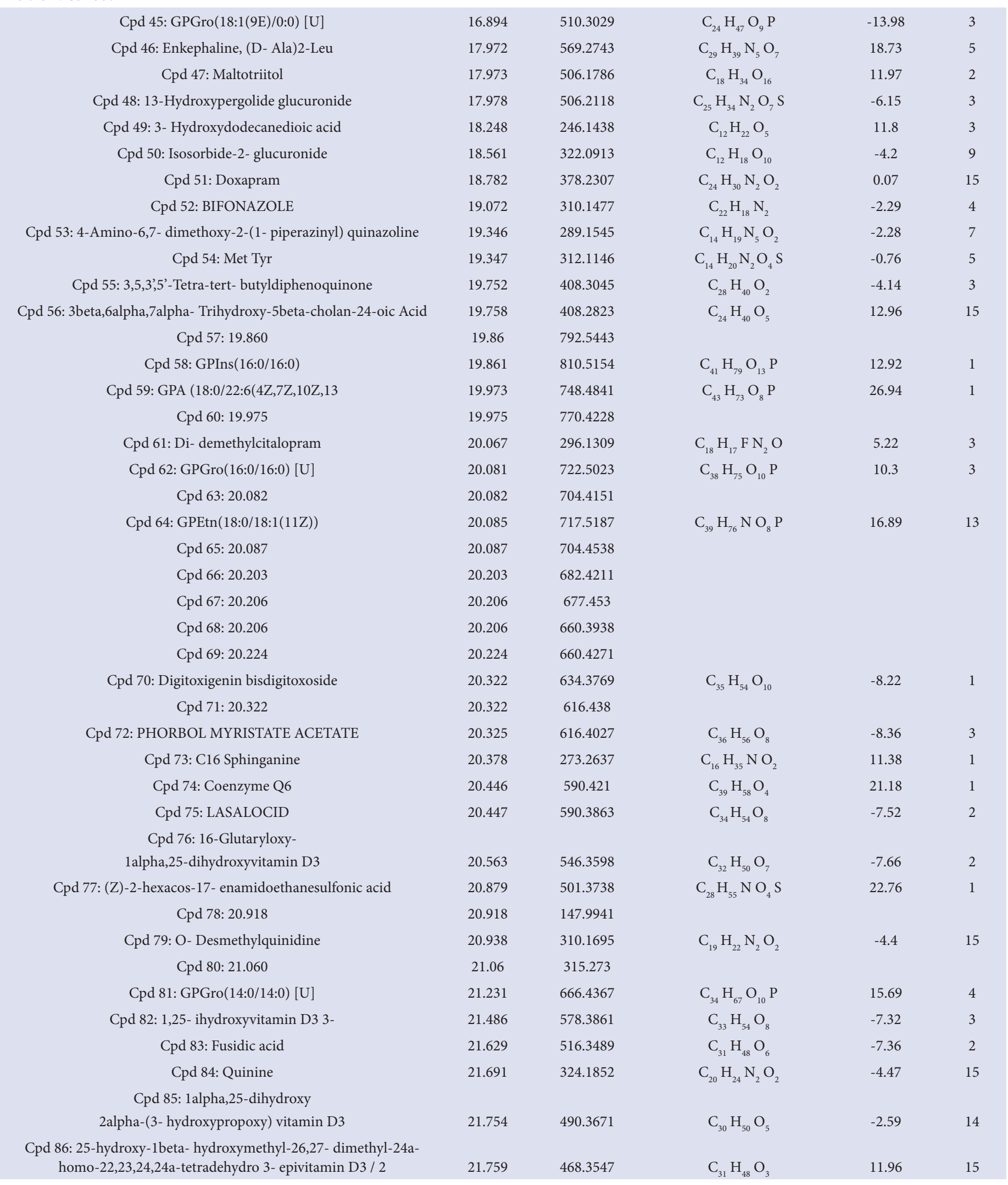


Table 2: Cont'd.

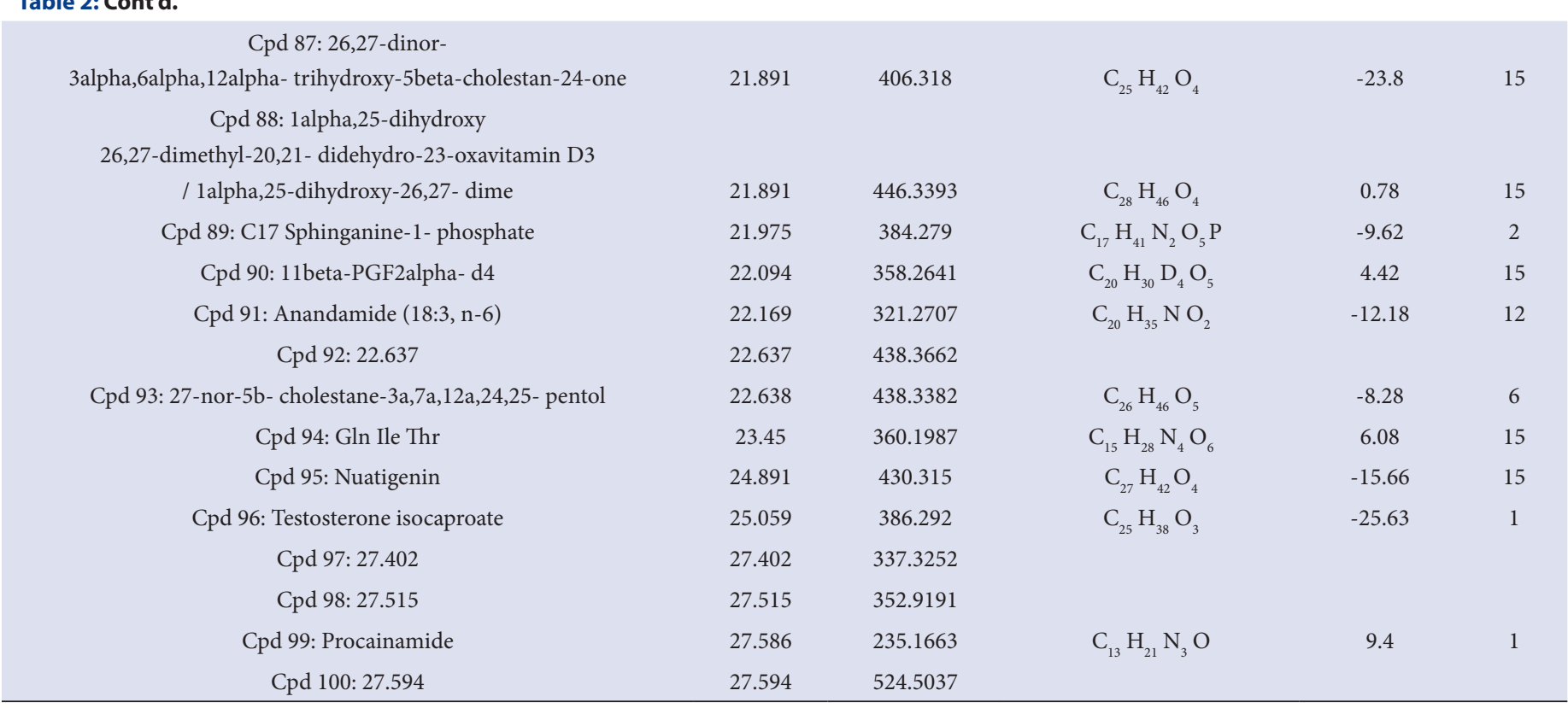

Table 3: Zone of inhibition and MIC values of LCME against pathogenic bacterial strains.

\begin{tabular}{ccccccc}
\hline SL. & & \multicolumn{5}{c}{ Inhibition zone diameter $(\mathrm{mm})$ and MIC $\left(\mathrm{mg} / \mathrm{ml}^{-1}\right)$} \\
\cline { 2 - 6 } & Microorganism & $\begin{array}{c}\text { Zl of LCME } \\
(1500 \mu \mathrm{g} / \text { well })\end{array}$ & $\begin{array}{c}\text { Activity } \\
\text { index }\end{array}$ & MIC & $\begin{array}{c}\text { Zl of Ciprofloxacin } \\
(20 \mu \mathrm{g} / \text { well })\end{array}$ & MIC \\
\hline 1 & S.aureus & $17.67 \pm 0.88$ & 0.697 & $1.10 \pm 0.15 \times 10^{-2}$ & $25.33 \pm 0.67$ & $3.16 \pm 0.10 \times 10^{-3}$ \\
2 & S.pneumoniae & $13.67 \pm 0.33$ & 0.494 & $7.12 \pm 0.01 \times 10^{-2}$ & $27.67 \pm 0.33$ & $3.16 \pm 0.10 \times 10^{-3}$ \\
3 & V.cholerae & $15.33 \pm 0.33$ & 0.605 & $3.10 \pm 0.15 \times 10^{-2}$ & $25.33 \pm 0.88$ & $5.82 \pm 0.10 \times 10^{-3}$ \\
4 & P.aeruginosa & $16.33 \pm 0.67$ & 0.620 & $6.30 \pm 0.10 \times 10^{-2}$ & $26.33 \pm 0.33$ & $0.60 \pm 0.30 \times 10^{-3}$ \\
5 & S.typhi & $17.67 \pm 0.33$ & 0.757 & $1.20 \pm 0.01 \times 10^{-2}$ & $24.33 \pm 0.33$ & $1.56 \pm 0.10 \times 10^{-3}$ \\
\hline
\end{tabular}

Values are mean \pm standard error $(\mathrm{n}=3)$ of three different samples, analyzed individually in triplicate, $\mathrm{ZI}$, the diameter of inhibition zone (mm) including well diameter of $6 \mathrm{~mm}$, MIC, minimum inhibitory concentration $(\mathrm{mg} / \mathrm{ml})$. AI (Activity Index) $=$ ZI of Test $/ \mathrm{ZI}$ of Standard.

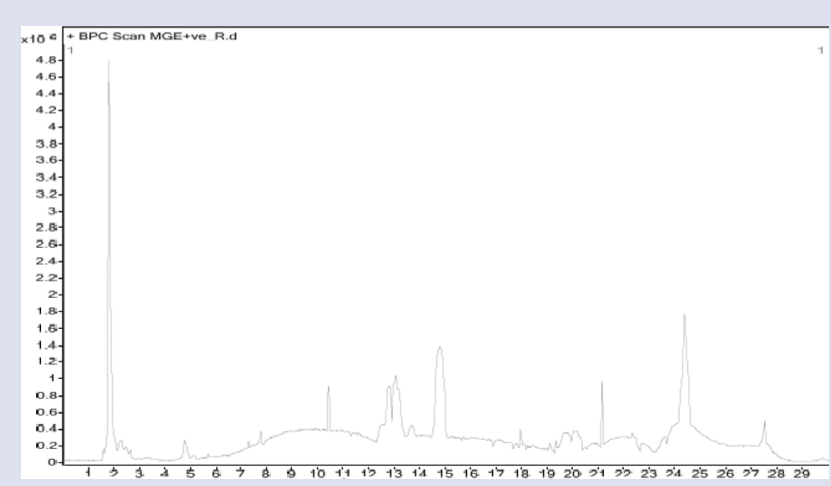

Figure 2: HR-LCMS Chromatograph of B. scandens leaf calli methanol extract

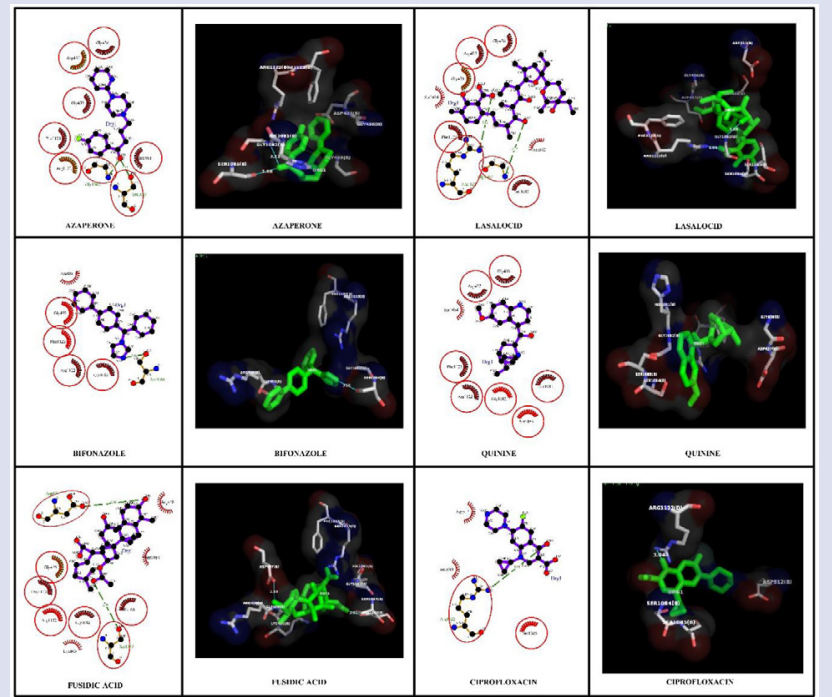

Figure 3:2D and 3D protein-ligand interaction DNA gyrase with the ligands azaperone bifonazole, fusidic acid and lasalocid. 
Table 4: In silico ADMET and drug likeness prediction using data warrior.

\begin{tabular}{ccccccc}
\hline Compounds & CLogP & CLogS & H-Acceptors & H-DONORS & TPSA & Drug likeness \\
\hline Azaperone & 2.76 & -3.42 & 4 & 0 & 36.44 & 5.409 \\
Bifonazole & 4.757 & -6.844 & 2 & 0 & 17.82 & 2.0429 \\
Fusidic acid & 5.823 & -5.363 & 6 & 3 & 104.06 & 0.050 \\
Lasalocid & 5.363 & -6.118 & 8 & 4 & 133.52 & 2.5589 \\
Quinine & 2.61 & -3.09 & 4 & 1 & 45.59 & 0.878 \\
\hline
\end{tabular}

Table 5: Molecular docking values of LCME compounds obtained from LCMS analysis.

\begin{tabular}{|c|c|c|c|c|c|}
\hline LIGAND & AFFINITY (kcal/mol) & H-BONDS & H-BOND LENGTH (Å०) & H-BOND WITH & HYDROPHOBIC INTERACTIONS \\
\hline \multirow{2}{*}{ azaperone } & \multirow{2}{*}{-4.4} & \multirow{2}{*}{2} & 2.98 & 2XCT:Ser1085::AZA:OAB & \multirow{2}{*}{$\begin{array}{c}\text { Gly436, Asp437, Gly459, His1081, } \\
\text { Arg1122, Phe1123 }\end{array}$} \\
\hline & & & 3.11 & 2XCT:Gly1082::AZA:OAB & \\
\hline bifonazole & -4.3 & 1 & 3.18 & 2XCT:Ser1084::BIF:NAB & $\begin{array}{c}\text { Arg458, Gly459, Gly1082,Arg1122, } \\
\text { Phe1123 }\end{array}$ \\
\hline \multirow{2}{*}{ fusidic acid } & \multirow{2}{*}{-4.7} & \multirow{2}{*}{2} & 2.89 & 2XCT:Asp437::FUS:OAC & \multirow{2}{*}{$\begin{array}{l}\text { Arg458,Gly459, Lys460, His1081, } \\
\text { Gly1082, Ser1084, Arg1122, Phe1123, }\end{array}$} \\
\hline & & & 2.91 & 2XCT:Ser1085::FUS:OAF & \\
\hline \multirow[b]{2}{*}{ lasalocid } & \multirow[b]{2}{*}{-4.9} & \multirow[b]{2}{*}{2} & 2.86 & 2XCT:Arg1122::LAS:OAC & \multirow[b]{2}{*}{$\begin{array}{l}\text { Gly436, Asp437, Gly459, Asp512, } \\
\text { Ser1084, Ser1085, Phe1123, }\end{array}$} \\
\hline & & & 3.09 & 2XCT:Gly1082::LAS:OAE & \\
\hline quinine & -4.6 & - & - & - & $\begin{array}{c}\text { Cys300, Gly301, Leu484, Glu488, } \\
\text { Leu601, Ala602, Lys603, Ser604, } \\
\text { Val605 }\end{array}$ \\
\hline ciprofloxacin & -4.4 & 1 & & 2XCT:Arg1122::CIP:OAQ & Asp512, Ser1084, Ser1085 \\
\hline
\end{tabular}

S.aureus with a significant MIC value of $1.10 \pm 0.15 \times 10^{-2}$. Inhibition of bacterial strains are summarized in Table 3.

\section{Toxicity prediction}

Result of pharmacokinetic properties and toxicity analysis of 5 compounds (azaperone, bifonazole, fusidic acid, lasalocid and quinine) identified by HR-LCMS is shown in Table 4. All the 5 compounds obey the Lipinski's 'Rule of 5 limit better LogS values and were free from mutagenic tumorigenic, reproductive and irritant effect. In general, a poor solubility is associated with bad absorption and the aqueous solubility ( $\log S$ ) of the compound which significantly affects its absorption and distribution characteristics. Based on the results from the DataWarrior, LogP, better LogS, good drug score and less toxicity risk parameters are predicted as shown in the Table 4.

\section{Molecular Docking}

In association with in vitro antimicrobial activity, it is useful to carry out in silico studies to predict the orientation and binding affinity at the active site of the receptor. The molecular docking of HR-LCMS identified ligand molecules- azaperone, bifonazole, fusidic acid, lasalocid and quinine with bacterial enzyme DNA gyrase is shown in Figure 3. Among them the compound lasalocid exhibited better docking efficiency with DNA gyrase. It forms two hydrogen bonds with amino acids Arg1122, and Gly1082 in the active site of the target protein with bond length 2.86 and 3.09 respectively, with the least binding affinity -4.9 and hence is considered as the best dock conformation (Table 5). Compound azaperone forms two hydrogen bonds with Gly1082 and Ser1085 amino acids with bond length 3.11 and $2.98 \AA$. The compound bifonazole forms only one hydrogen bond with the amino acid Ser108 with bond length $3.18 \AA$ and the compound Fusidic acid forms two hydrogen bonding with Asp437 and Ser1085 with bond length 2.89 and $2.91 \AA$ respectively. While compound quinine doesn't form hydrogen bond with the aminoacids of the active pocket. However, all these docked molecules exhibited more hydrophobic interaction than the standard drug ciprofloxacin. The RMSD has often been used to measure the quality of reproduction of a known binding pose by molecules with ligands. All docked molecules have zero RMSD values as shown in the Table 5.

\section{DISCUSSION}

Medicinal plants have been used as a source of medicine in all cultures since times immemorial. ${ }^{18}$ Even though World Health Organization reported that the primary health care system for the $60 \%$ population of the world is represented by the traditional medicines yet a great number of plant species with potential biological activities were unexplored. ${ }^{19}$ The extracts of several medicinal plants are very effective against microbial as well as parasitic infections. ${ }^{20}$ Although synthetic or chemical drugs as compared to herbal medicines can have greater or quicker effects, but they possess many adverse effects and risks. ${ }^{21}$ Herbal medicines are generally less expensive as compared to synthetic ones.

The continuous exploitation of several medicinal plant species from the wild. $^{22}$ and substantial loss of their habitats during past 15 years have resulted in population decline of many high value medicinal plant species over the years. The primary threats to medicinal plants are those that affect any kind of biodiversity used by humans. ${ }^{23,24}$ Attempts are 
being made by different organizations to cultivate various medicinal plant species, including rare and endangered categories. ${ }^{25}$ Evidence that plant cell cultures are able to produce secondary metabolites came quite late in the history of in vitro techniques. ${ }^{26}$

Callus culture is very useful to obtain commercially important secondary metabolites or drugs can be directly extracted from the callus tissues without scarifying the whole plant. In the present study, HR-LCMS analysis of LCME showed the presence of various compounds. Among them the compounds azaperone, bifonazole, fusidic acid, lasalocid and quinine are reported as good antibacterial agents ${ }^{27-30}$ As compared to in vivo plant parts the de novo synthesis of secondary metabolites takes place in the in vitro derived calli due to the influence of hormones supplemented in the media. The standardized technique can be explored commercially for the mass production of compounds.

S. aureus bacteremia is a significant cause of morbidity and mortality in neutropenic patients with cancer. ${ }^{31}$ In the present study LCME of B. scandens exhibited significant inhibitory effect on both gram positive Staphylococcus aureus, Streptococcus pneumoniae. Pseudomonas aeruginosa and gram negative Salmonella typhi, Vibrio cholera, strains which causes pneumonia (lung infection), osteomyelitis (bone infection), endocarditis (heart infection), phlebitis (infection of veins and blood vessels), mastitis (infection of breast and formation of abscesses) and meningitis (brain infections).in humans. Previous investigator Adeeba Anjum. ${ }^{32}$ evaluated the antibacterial property of $B$. scandens leaf and stem bark against 13 bacterial clinical isolates both gram positive (Bacillius cereus, Bacillus megaterium, Bacillus subtilis, Sarcina lutea, Staphylococcus aereus) and gram negative (Escherichia coli, Pseudomonas aeruginosa, Salmonella paratyphi, Salmonella typhi, Shigella boydii, Shigella dysenteriae, Vibro meniscus, Vibrio parahaemolyticus) The methanol extract of the leaf exhibited the highest activity against $S$. lutea of $21.6 \mathrm{~mm}$ and for $S$. aereus $19.1 \mathrm{~mm}$ ZI. LCME shows $17.6 \mathrm{~mm}$ ZI. The antibacterial property of LCME is due the cumulative effect of the compounds azaperone, bifonazole, fusidic acid, lasalocid and quinine and it was supported by molecular docking studies. The in silico docking of lasalocid with the DNA gyrase showed higher binding affinity as well as hydrogen bonding and good hydrophobic interaction with the receptor. Among these 5 ligands lasalocid showed highest binding affinity and hydrophobic interaction with the amino acids of the active pocket. DNA gyrase is an essential bacterial enzyme that catalyzes the introduction of negative (-) supercoils into chromosomal and plasmid DNA. Gyrase was discovered soon after it was clear that in vitro recombination of bacteriophage $\lambda$ required a negatively supercoiled DNA substrate. DNA gyrase cleave and religate DNA to regulate DNA topology and are a major class of antibacterial and anticancer drug targets. ${ }^{33}$ The 5 ligand molecules exhibited the antibacterial activity by hindering the function of DNA gyrase.

\section{CONCLUSION}

Leaf calli methanol extract of B. scandens contains good antibacterial compounds azaperone, bifonazole, fusidic acid, lasalocid and quinine. The antibacterial activity was more significant against $S$. aureus. In silico docking studies also supported the inhibition of DNA gyras with highest bonding efficiency and hydropobic interaction. Due to unscientific over exploitation many of the medicinal are becoming endangered. The harvesting of antibacterial compunds from the in vitro grown leaf calli of Bridelia scandens is a better method to combat contagious microbial diseases.

\section{ACKNOWLEDGEMENT}

The authors are thankful to DBT, New Delhi, India for providing financial support through DBT- BUILDER program (Order No. BT/PR9128/
INF/22/190/2013, Dated: 30/06/2015) and the Kuvempu University administrative authority for offering the facility to carry out the work.

\section{CONFLICT OF INTEREST}

No Conflict of Interest.

\section{ABBREVIATIONS}

LCME: Leaf callus methanol Extract; BAP: 6-Benzylaminopurine; 2.4D: 2,4-Dichlorophenoxyacetic acid; MS: Murashige and Skoog; DMSO: Dimethyl sulfoxide; RMSD: Root Mean Square Deviation; ZI: Zone of Inhibition; MIC: Minimum Inhibitory Concentration; HR-LCMS-: High Resolution Liquid Chromatograph Mass Spectrometer; ADMET: Absorption, Distribution, Metabolism, Excretion and Toxicity.

\section{REFERENCES}

1. Wala BB, JasraiYT. Micropropagation of an endangered medicinal plant: Curculigo orchioides Gaertn. Plant Tissue Cult. 2003;13(1):13-9.

2. Senthil KD, Kottai MA, Satheesh KRMD. In-vitro antioxidant potential of various extracts of whole plant of Bridelia scandens (Roxb) wild. International Journal of Drug Development and Research. 2010;2(1):40-6.

3. Gomathi V, Jaykar B. Antidiabetic activity of ethanolic leaf extract of Bridelia scandens in streptozotocin induced diabetic rats. Journal of Pharmacy Research 2015;9(3):190-3.

4. Shankar MK. "In vitro studies and comparative screening of hepatoprotective activities of some medicinal plants Malnad region of Karnataka." (2006).

5. Borges A, Saavedra MJ, Simões M. Insights on antimicrobial resistance, biofilms and the use of phytochemicals as new antimicrobial agents. Curr Med Chem. 2015;22(21):2590-614.

6. Deurenberg RH, Stobberingh EE. The evolution of Staphylococcus aureus. Infect Genet Evol. 2008;8(6):747-63.

7. Mandal SM, Roy A, Ghosh AK, Hazra TK, Basak A, Franco OL. Challenges and future prospects of antibiotic therapy: from peptides to phages utilization. Front Pharmacol. 2014;5:105.

8. Lajiness MS, Vieth M, Erickson J. Molecular properties that influence oral drug-like behavior. Curr Opin Drug Discov Devel. 2004;7(4):470-7.

9. Rudnitskaya A, Török B, Török M. Molecular docking of enzyme inhibitors. Biochem Mol Biol Educ. 2010;38(4):261-5.

10. Chang $\mathrm{C}-\mathrm{C}$, Yang $\mathrm{M}-\mathrm{H}$, Wen $\mathrm{H}-\mathrm{M}$, Chern J-C. Estimation of Total Flavonoid Content in Propolis by Two Complementary Colorimetric Methods. J Food Drug Anal. 2002;10(3):178-82

11. Zhishen J, Mengcheng T, Jianming $W$. The determination of flavonoid contents in mulberry and their scavenging effects on superoxide radicals. Food Chem. $1999 ; 64(4): 555-9$

12. Edeoga HO, Okwu DE, Mbaebie BO. Phytochemical constituents of some Nigerian medicinal plants. African J Biotechnol. 2005;4(7):685-8.

13. Pradeep K, Krishna V, Harish BG, Venkatesh R, Santosh Kumar SR, Girish Kumar K. Antibacterial activity of leaf extract of Delonix elata and molecular docking studies of Luteolin. J Biochem Technol. 2014;3(5):193-7.

14. Sarker SD, Nahar L, Kumarasamy Y. Microtitre plate-based antibacterial assay incorporating resazurin as an indicator of cell growth, and its application in the in vitro antibacterial screening of phytochemicals. Methods. 2007;42(4):321-4.

15. Bax BD, Chan PF, Eggleston DS, et al. Type IIA topoisomerase inhibition by a new class of antibacterial agents. Nature. 2010;466(7309):935-40.

16. Trott O, Olson AJ. AutoDock Vina: improving the speed and accuracy of docking with a new scoring function, efficient optimization, and multithreading. J Comput Chem. 2010;31(2):455-61.

17. Laskowski RA, Swindells MB. LigPlot+: Multiple Ligand-Protein Interaction Diagrams for Drug Discovery. J Chem Inf Model. 2011;51(10):2778-86.

18. Malik F, Hussain D, Dil AS, Hannan AAHG. WHO Global Atlas of Traditional, Complementary and Alternative Medicine (Map Volume). In: WHO Global Atlas of Traditional, Complementary, and Alternative Medicine. World Health Organization, Centre for Health Development; 2005:165-9.

19. Li JW-H, Vederas JC. Drug Discovery and Natural Products: End of an Era or an Endless Frontier? Science (80). 2009;325(5937):161-5

20. Haider Z, Sheikh MA, Shahid M, Ahamed A, Ali SM. Antihepatotoxic evaluation of Butea monosperma against liver damage induced by rifampicin and paracetamol in chicks. Pakistan J Biochem Mol Biol. 2002.

21. Haq I. Safety of medicinal plants. Pak J Med Res. 2004;43(4):203-10.

22. Kala CP. Commercial exploitation and conservation status of high value medicinal plants across the borderline of India and Nepal in Pithoragarh. Indian For. 2003;129(1):80-4.

23. Rao MR, Palada MC, Becker BN. Medicinal and aromatic plants in agroforestry 
systems. In: New Vistas in Agroforestry. Springer, Dordrecht; 2004:107-22.

24. Sundriyal R, Sharma E. Cultivation of medicinal plants and orchids in Sikkim Himalaya. Almora GB Pant Inst Himal Environ. 1995.

25. Kala C, Dhyani P, Sajwan B. Developing the medicinal plants sector in northern India: challenges and opportunities. J Ethnobiol Ethnomed. 2006;1(2):32.

26. Krikorian AD. Chapter Seven - Biochemical Differentiation: The Biosynthetic Potentialities of Growing and Quiescent Tissue. In: Plant Physiology. 1969:227-326.

27. LacknerTE, Clissold SP. Bifonazole. Drugs. 1989;38(2):204-25.

28. Iwu MW, Duncan AR, Okunji CO. New antimicrobials of plant origin. Perspectives on new crops and new uses. ASHS Press, Alexandria, VA. 1999:457-62.

29. Falagas ME, Grammatikos AP, Michalopoulos A. Potential of old-generation antibiotics to address current need for new antibiotics. Expert Rev Anti Infect Ther. 2008;6(5):593-600.
30. Huczynski A, Rutkowski J, Wietrzyk J, et al. X-ray crystallographic, FT-IR and NMR studies as well as anticancer and antibacterial activity of the salt formed between ionophore antibiotic Lasalocid acid and amines. J Mol Struct. 2013;1032:69-77.

31. González-Barca E, Carratalá J, Mykietiuk A, Fernández-Sevilla A, Gudiol F Predisposing Factors and Outcome of Staphylococcus aureus Bacteremia in Neutropenic Patients with Cancer. Eur J Clin Microbiol Infect Dis. 2001; 20(2):117-9.

32. Anjum A, Haque MR, Rahman MS, Hasan CM, Haque E, Rashid MA. In vitro antibacterial, antifungal and cytotoxic activity of three Bangladeshi Bridelia species. 2011;1(7):149-54.

33. Reece RJ, Maxwell A. DNA Gyrase: Structure and Function. Crit Rev Biochem Mol Biol. 1991;26(3-4):335-75.

\section{GRAPHICAL ABSTRACT}

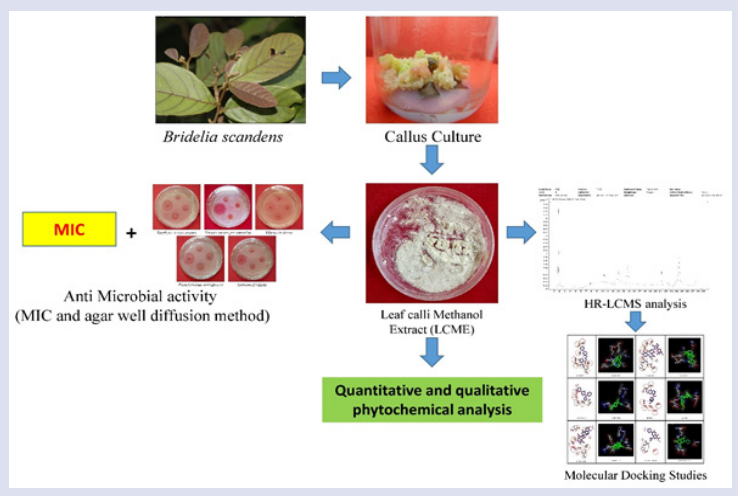

\section{SUMMARY}

- Evaluation of antibacterial activity and molecular docking studies of B. scandens leaf Calli extract was performed.

- LCME show significant antibacterial activity against selected human clinical pathogens.

- And the molecular docking shows phyto components obtained from the LCME shows good inhibition against bacterial DNA gyrase.

- The present study shows that the LCME is a good antibacterial agent against human clinical pathogen.

\section{ABOUT AUTHORS}

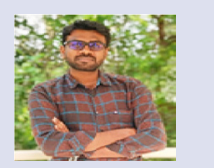

Mr.Ravikumar S, Research Scholar, Department of Biotechnology, Kuvempu University. He is having two years of research experience.

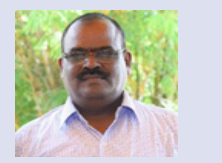

Dr. V Krishna, Professor, Department of PG studies and research in Biotechnology, Kuvempu University. He is having 27 years of teaching and research experience in the field of Plant tissue culture, Phytochemistry and Pharmacology. He is currently running 5 crore project and has received research grants from various funding agencies like DBT, DST, UGC etc. He has published 185 research papers in international and national peer reviewed journals. He is having one patent to his credit.

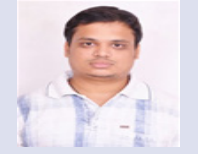

Mr. Sudhesh Shastri, Research Scholar, Department of Biotechnology, Kuvempu University. He is having three years of research experience. He has published two research articles in peer reviewed journals.

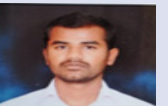

Mr. Ravishankara B, Research Scholar, Department of Biotechnology, Kuvempu University. He is having two years of research experience.

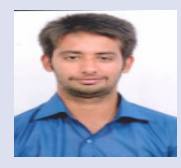

Mr. Ajith S, Research Scholar, Department of Biotechnology, Kuvempu University. He is having two years of research experience.

Cite this article: Shivakumar R, Venkatarangaiah K, Shastri S, Nagaraja RB, Sheshagiri A. Antibacterial Property and Molecular Docking Studies of Leaf Calli Phytochemicals of Bridelia scandens Wild.Pharmacog J. 2018;10(6):1221-9. 